\title{
Cepharanthine Induces Autophagy, Apoptosis and Cell Cycle Arrest in Breast Cancer Cells
}

\author{
Sumei Gao ${ }^{\mathrm{a}}$ Xiaoyan Lia Xia Ding ${ }^{\mathrm{b}}$ Wenwen Qja ${ }^{\mathrm{a}}$ Qifeng Yang ${ }^{\mathrm{a}, \mathrm{c}}$ \\ aDepartment of Breast Surgery, Qilu Hospital, Shandong University, Jinan, bepartment of Oncology, \\ Qilu Hospital, Shandong University, Jinan, 'Pathology Tissue Bank, Qilu Hospital, Shandong University, \\ Jinan, P.R. China
}

\section{Key Words}

Cepharanthine $\cdot$ Autophagy $•$ Apoptosis $•$ Cell cycle arrest $•$ Breast cancer cells

\begin{abstract}
Background: Cepharanthine (CEP) is a biscoclaurine alkaloid extracted from Stephania cepharantha and has been shown to have an anti-tumour effect on different types of cancers. However, the anti-cancer effect of CEP on human breast cancer cells is still unclear. Methods: We used MTT, clone formation, in vitro scratch, invasion and migration assays to confirm the inhibitory role of CEP on the proliferation of breast cancer cells. Flow cytometry, plasmid construction and western blot analysis were used to study the detailed mechanisms. Results: Our study showed that CEP could inhibit cell proliferation by inducing autophagy, apoptosis, and G0/G1 cell cycle arrest of breast cancer cells. Furthermore, we found that CEP induced autophagy and apoptosis by inhibiting the AKT/mTOR signalling pathway. Conclusion: We found that CEP could inhibit growth and motility of MCF-7 and MDA-MB-231 breast cancer cell. Our study revealed an anti-tumour effect of CEP on breast cancer cells and suggests that CEP could be a potential new clinical therapy for breast cancer.

\section{Introduction}

Breast cancer is one of the most common types of malignant tumour, and in recent years, it has been the second leading cause of death among females around the world [1]. In 2015, approximately 4,292,000 Chinese women were diagnosed with breast cancer, and 2,814,000 died from this disease [2]. The standard treatments for breast cancer include surgical operation, chemotherapy, radiotherapy, endocrine therapy, target therapy and other supplement therapies. However, most of these traditional treatments cause side effects that affect the quality of life of patients [3]. It is therefore necessary to explore new therapies for breast cancer patients, that will improve their prognosis and quality of life. 
Traditional Chinese medicine (TCM) has a long history in China. TCM contains a variety of complex compounds, such as alkaloids, flavonoids and polysaccharides [4, 5]. TCM has anti-tumour effects on different types of cancer, including ovarian, colon, lung, prostate and breast [6-8]. Therefore, in recent years, TCM has been widely used as an adjunctive therapy for cancer $[9,10]$. Huaier extract, a typical representative of TCM, exhibited an anticancer effect on various kinds of cancers [11]. In our previous studies, we found that Huaier extract could inhibit angiogenesis by targeting tumour-associated macrophages [12], induce autophagy cell death [13], inhibit proliferation of breast cancer cells by inducing apoptosis [14], synergize with Tamoxifen to induce autophagy and apoptosis [15], and sensitize breast cancer cells to radiotherapy [16].

Cepharanthine (CEP, Fig. 1A) is a natural alkaloid extracted from Stephania cepharantha Hayata [17]. CEP has shown several types of its anti-cancer effects, including inhibition of cell proliferation [18], anti-angiogenesis effects [19], induction of autophagy cell death [20], prevention of metastasis [21], sensitization to anticancer agents or radiation [22-25], and anti-inflammatory effects [26]. It has been reported that CEP could induce apoptosis and autophagy in several cancers, but whether it has an anti-cancer effect on breast cancer is unknown. In our study, for the first time, we demonstrated the anti-cancer effects of CEP on human MCF-7 and MDA-MB-231 breast cancer cell lines. Furthermore, we revealed the antitumour molecular mechanism of CEP activity in breast cancer cells.

\section{Materials and Methods}

\section{Cell lines and reagents}

The human breast cancer cell lines MDA-MB-231 and MCF-7 were purchased from the American Type Culture Collection (ATCC, Manassas, VA, USA). An Annexin V-FITC/PI assay kit was purchased from BD Bioscience (Franklin Lakes, NJ, USA). A caspase peptide inhibitor (Z-VAD-FMK) and Anti-Bax were purchased from Beyotime Institute of Biotechnology (Jiangsu, China). Anti-ATG-7 was obtained from Abgent (San Diego, USA). Monoclonal antibodies against caspase-3 and caspase-9, phospho-Akt (ser473) and Akt, phosphomTOR, m-TOR, P21, p-Rb (Ser795), Cyclin D1 and CDK4, LC3B, P62 and Beclin1 were purchased from Cell Signaling Technology (CST, Beverly, MA, USA). Anti-BCL-2 was purchased from Dako Corp (Carpinteria, CA, USA). The reagents 3-(4,5-dimethylthiazol-2-yl)-2,5-diphenyltetrazolium bromide (MTT), 3-methyladenine (3-MA), chloroquine (CQ), dimethyl sulfoxide (DMSO), 5-fluorouracil (5-Fu), penicillin, streptomycin and acridine orange were obtained from Sigma-Aldrich (St. Louis, MO, USA). Rapamycin (Rapa) was purchased from Gene Operation (Ann Arbor, Michigan, USA). Dulbecco's modified Eagle's medium (DMEM) was from Gibco (Rockville, IN, USA) and foetal bovine serum (FBS) from Clark Bioscience (Seabrook, MD, USA).

Cepharanthine was purchased from Tauto Biotech (Shanghai, China) with a purity exceeding 96\%, and it was dissolved in DMSO. DMSO was used as the control treatment.

\section{Cell culture}

MCF-7 and MDA-MB-231 cells were routinely cultured in a humidified $5 \% \mathrm{CO}_{2}$ incubator $\left(37^{\circ} \mathrm{C}\right)$, in Dulbecco's modified Eagle's medium supplemented with $10 \%$ foetal bovine serum (FBS), $100 \mathrm{U} / \mathrm{mL}$ penicillin and $100 \mu \mathrm{g} / \mathrm{mL}$ streptomycin.

\section{Plasmid construction and transfection}

For overexpression of AKT in breast cancer cells, AKT cDNA was cloned into the multiple cloning site of the pcDNA3.1 vector (Invitrogen, Carlsbad, CA, USA). The expression plasmid vector and the empty vector were used to transfect MCF-7 and MDA-MB-231 cells using Lipofectamine 2000 (Invitrogen, Carlsbad, CA, USA) to establish AKT overexpression (pcDNA3.1-AKT) and control (pcDNA3.1-vector) cell lines.

Cell viability assay

Cell viability was examined by 3-(4,5-dimethylthiazol-2-yl)-2,5-diphenyltetrazolium bromide (MTT) assay. MCF-7 $\left(3 \times 10^{3}\right.$ cells/well) and MDA-MB-231 $\left(4 \times 10^{3}\right.$ cells/well) cells were seeded into 96 -well culture plates and incubated in $5 \% \mathrm{CO}_{2}$ at $37^{\circ} \mathrm{C}$. After incubation overnight, the cells were exposed to vehicle or CEP 


\section{Cellular Physiology Cell Physiol Biochem 2017;41:1633-1648

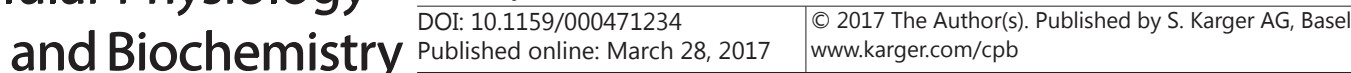

Gao et al.: The Effect of Cepharanthine on Breast Cancer Cells

for 24,48 , and $72 \mathrm{~h}$. Then, $20 \mu \mathrm{L}$ of MTT ( $5 \mathrm{mg} / \mathrm{mL}$ ) was added to each well, and the cells were incubated for another $4 \mathrm{~h}$ at $37^{\circ} \mathrm{C}$. After removal of MTT, $100 \mu \mathrm{L}$ of DMSO was added to each well, and the plate was gently shaken for $10 \mathrm{~min}$ at room temperature. The absorbance was measured with the Microplate Reader (Bio-Rad, Hercules, CA, USA) at $490 \mathrm{~nm}$. All experiments were repeated at least three times.

\section{Colony forming assay}

MCF-7 and MDA-MB-231 cells were treated with different concentrations of CEP for $24 \mathrm{~h}$. Nextthe cells were seeded in 6-cm Petri dishes (1500 cells per dish) and cultured in complete medium for 14 days. The medium was refreshed every three days. Thereafter, the cells were washed with phosphate-buffered saline (PBS), fixed with paraformaldehyde and stained with $0.5 \%$ crystal violet. Images of colonies were taken using an Olympus digital camera (Olympus, Tokyo, Japan).

\section{In vitro scratch assay}

To evaluate how CEP affect migration ability, a scratch assay was performed with the MCF-7 and MDAMB-231 cells. MCF-7 and MDA-MB-231 cells were harvested by trypsinization and were seeded in 24-well plates at a density of $3 \times 10^{5}$ or $2 \times 10^{5}$, respectively. Cells, at confluency, were grown in complete medium for $24 \mathrm{~h}$. After then the cells were scraped with p20 pipette tips to create a straight-line "scratch". Reference points near the "scratch" were marked to guarantee the same area of image acquisition. The cells were treated with different concentrations of CEP ( $5 \mu \mathrm{M}$ for MCF-7, $4 \mu \mathrm{M}$ for MDA-MB-231), and images were taken at intervals of $12 \mathrm{~h}$ and $24 \mathrm{~h}$. The images were analysed quantitatively by Image-Pro Plus.

\section{Invasion and migration assays}

The invasion assay was performed using the Transwell system (Corning Costar, Lowell, MA, USA) to detect any CEP-induced changes to the invasiveness of MDA-MB-231 cells. MDA-MB-231 cells $\left(1 \times 10^{5}\right)$ were suspended in serum-free medium and then added to the upper inserts, and $700 \mu \mathrm{L}$ of complete medium with $20 \%$ FBS was added to the lower well of each chamber. After incubation for $24 \mathrm{~h}$, the wells were collected. The migration assay was performed in the same way as the invasion assay above except that the membrane was not coated with Matrigel. MDA-MB-231 and MCF-7 cells $\left(1 \times 10^{5}\right)$ were added to the upper wells. The cells from the appropriate wells were collected after $15 \mathrm{~h}$ (MDA-MB-231) or $48 \mathrm{~h}$ (MCF-7). The total number of cells invading and adhering to the lower surface was acquired with an Olympus light microscope (Tokyo, Japan).

\section{Cell-cycle analysis}

$3 \times 10^{5}$ cells/well was seeded into a 6-cm Petri dish. After $24 \mathrm{~h}$ incubation, the cells were treated with CEP for $24 \mathrm{~h}$ or $48 \mathrm{~h}$, then collected and fixed with $75 \%$ cold ethanol ( $1 \mathrm{~mL}$ PBS and $3 \mathrm{~mL}$ absolute ethanol) at $-20^{\circ} \mathrm{C}$ overnight. After that, the DNA of cells was incubated with $200 \mu \mathrm{L}$ RNase A (1 mg/mL) and 500 $\mu \mathrm{L}$ propidium iodide (PI, $100 \mu \mathrm{g} / \mathrm{mL}$ ) for $30 \mathrm{~min}$ at room temperature in the dark and analysed using the FACScan flow cytometer (Becton Dickinson, Franklin Lakes, NJ, USA). The data were analysed with ModFitLT V2.0 software (Becton Dickinson, Franklin Lakes, NJ, USA).

\section{Identification of apoptosis by PI-Annexin-V staining}

MCF-7 and MDA-MB-231 cells were cultured in 6-cm Petri dishes for $24 \mathrm{~h}$ prior to treatment. The cells were treated with different concentrations of CEP for $48 \mathrm{~h}$ and were harvested by trypsinization with $0.1 \%$ trypsin. Then, cells were stained with $5 \mu \mathrm{L}$ Annexin V-FITC and $5 \mu \mathrm{L}$ propidium iodide (PI) (20 $\mu \mathrm{g} / \mathrm{mL})$ and were incubated for $15 \mathrm{~min}$ in the dark at room temperature. Then, the cells were incubated with $200 \mu \mathrm{L}$ RNase A (1 mg/mL) for $30 \mathrm{~min}$ at room temperature in the dark. The apoptotic cells were detected using a FACScan flow cytometer, and the data were analysed using WinMDIV2.9 software (The Scripps Research Institute, San Diego, CA, USA).

\section{Immunocytochemical analysis}

Cells were seeded in 24-well plates on a coverslip and treated with CEP for $48 \mathrm{~h}$. Then, cells were fixed with $4 \%$ paraformaldehyde and stained with Acridine Orange $(1 \mu \mathrm{g} / \mathrm{mL})$. After that, the coverslips were fixed on the glass slides with anti-fading medium (Beyotime Institute of Biotechnology, Jiangsu, China). The slides were sealed by neutral resin and observed under a fluorescence microscope (Olympus, Tokyo, Japan). The images were analysed using ImageJ software.

\section{KARGER}




\section{Cellular Physiology Cell Physiol Biochem 2017;41:1633-1648

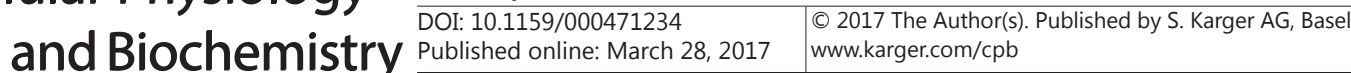 \\ Gao et al.: The Effect of Cepharanthine on Breast Cancer Cells}

Flow cytometry analysis of acidic vesicular organelles (AVO)

To evaluate the change in the number of AVOs in cells treated with CEP, cells were treated with different concentrations of CEP for $48 \mathrm{~h}$; then, cells were stained with Acridine orange $(1 \mu \mathrm{g} / \mathrm{mL})$ at room temperature for $15 \mathrm{~min}$ in the dark. The cells were washed immediately three times with PBS and were analysed in a FACScan flow cytometer. The data were analysed using BD Cell Quest software.

\section{Western blot analysis}

Cells were lysed with radioimmunoprecipitation assay (RIPA) buffer and PMSF (Biocolors, Shanghai, China) and quantified using the BCA protein concentration assay kit (Merck, Darmstadt, Germany). Fifty micrograms of proteins were separated by $10 \%$ SDS-PAGE and were electro-blotted onto a PVDF membrane using a semidry blotting apparatus (Bio-Rad, Hercules, CA, USA). After blocking with 5\% non-fat milk, the membranes were incubated with primary antibodies overnight at $4^{\circ} \mathrm{C}$. The next day, the membranes were labelled with secondary antibody, and signals were detected using a Luminescent Image analyzer (GE Healthcare Bio-Sciences, Uppsala, Sweden). $\beta$-actin was used as the endogenous control.

\section{Statistical analysis}

The results were analysed using SPSS software (SPSS, Chicago, IL, USA). Two-tailed Student's t-tests and one-way ANOVAs were performed to determine significance. Each experiment was performed three times, and differences were considered significant when $p$-values $<0.05$.

\section{Results}

CEP inhibited the proliferation of breast cancer cells

We used MTT and clone formation assays to demonstrate the effect of CEP on the proliferation of breast cancer cells. As shown in Fig. 1B, C, CEP inhibited the growth of MCF7 and MDA-MB-231 cells. The IC50 of CEP against MCF-7 and MDA-MB-231 cells at $24 \mathrm{~h}$ are shown in Table 1 . We demonstrated that MDA-MB-231 cells were more sensitive than MCF-7 cells to CEP-induced inhibition of proliferation. Furthermore, CEP inhibited the proliferation of both MCF-7 and MDA-MB-231 breast cancer cells in dose- and time-dependent manners. In the MCF-7 cells, a sharp decrease in cell viability was observed with $10 \mu \mathrm{M}$ CEP that was independent of the treatment time $(\mathrm{p}<0.01)$. However, a cytotoxic effect was observed in MDA-MB-231 cells treated with $6 \mu \mathrm{M}$ CEP for $24 \mathrm{~h}$ and $48 \mathrm{~h}$. The clone formation assay was used to evaluate the clone formation ability of MCF-7 and MDA-MB-231 cells. As shown in Fig. 1D, E, with increasing CEP concentration, the clone formation ability decreased in both cell lines.

\section{CEP inhibited the motility of breast cancer cells}

As shown in Fig. 2, we detected the effect of CEP on motility of breast cancer cells by using scratch, migration and invasion assays. The assays revealed similar results. Compared with untreated cells, MCF-7 and MDA-MB-231 cells treated with CEP exhibited inhibited migration (Fig. 2A, B). Fig. 2C revealed that the number of invading MDA-MB-231 cells in the

Table 1. Effect of CEP and 5-Fu on cell viability assessed by the MTT method. IC50 is the half maximal inhibitory concentration. The IC $50 \pm$ SD $(\mu \mathrm{M})$ were calculated based on the results of three independent experiments. IC50 value of CEP was compared with those of 5-Fu (positive control) in each cancer cell line at $24 \mathrm{~h}$

\begin{tabular}{lcc} 
& & IC50 $(\mu \mathrm{M})$ \\
& MCF-7 & MDA-MB-231 \\
\hline CEP (Cepharanthine) & $9.45 \pm 1.13$ & $5.61 \pm 1.51$ \\
5-Fu (5-Fluorouracil) & $11.45 \pm 1.20$ & $7.79 \pm 2.10$ \\
\hline
\end{tabular}




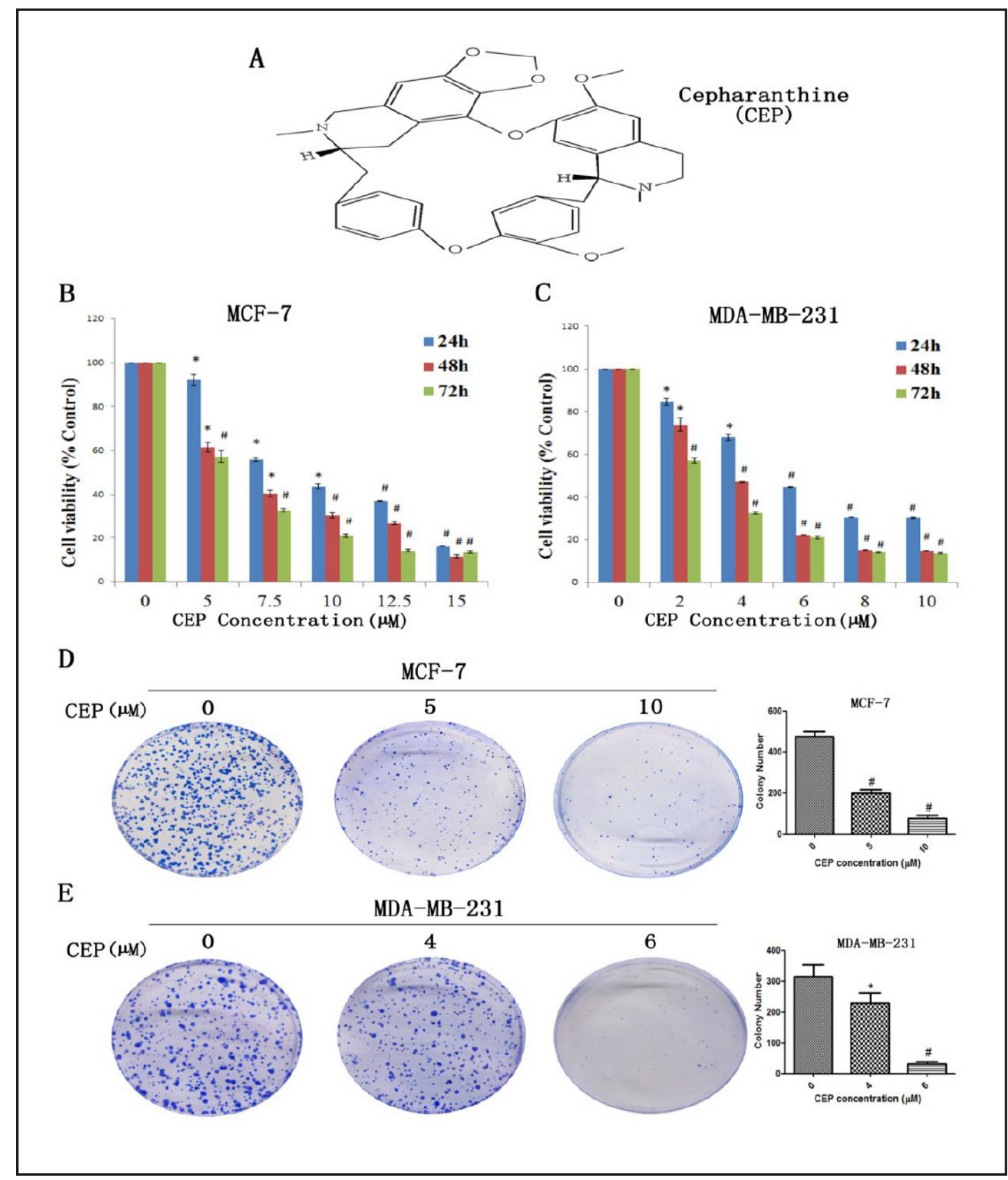

Fig. 1. The chemical structure of CEP (A). The effect of the indicated concentrations of CEP on MCF-7 (B) and MDA-MB-231 (C) cell viability were measured using MTT assay. Cells were treated with different concentrations of CEP for $24 \mathrm{~h}$; representative images of MCF-7 (D) and MDA-MB-231 (E) clone formation are shown. * $p<0.05$; ${ }^{*} p<0.01$ compared with the control. The data are presented as the mean \pm SD of three separate experiments.

CEP-treated group was significantly lower than in the untreated group. These data revealed that CEP could reduce the motility of breast cancer cells.

CEP induced cell cycle arrest in breast cancer cells

To determine the effect of CEP on cell cycle arrest in MCF-7 and MDA-MB-231 cells, the cell cycle distribution was investigated by flow cytometry. First, the cells were treated with different concentrations of CEP for $24 \mathrm{~h}$ and $48 \mathrm{~h}$, and then, the cells were examined by flow cytometry. Compared with the untreated cells, G0/G1 arrest was significantly induced KARGER 
A
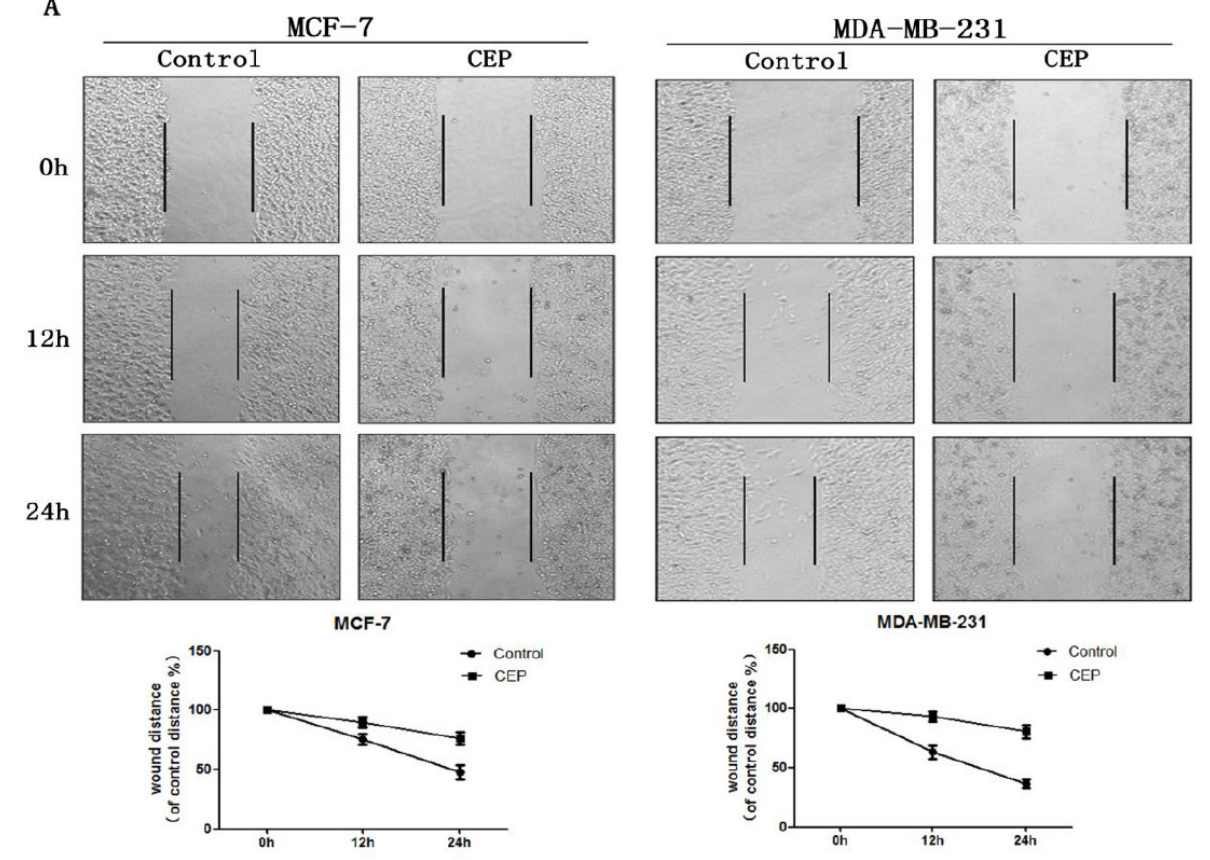

B
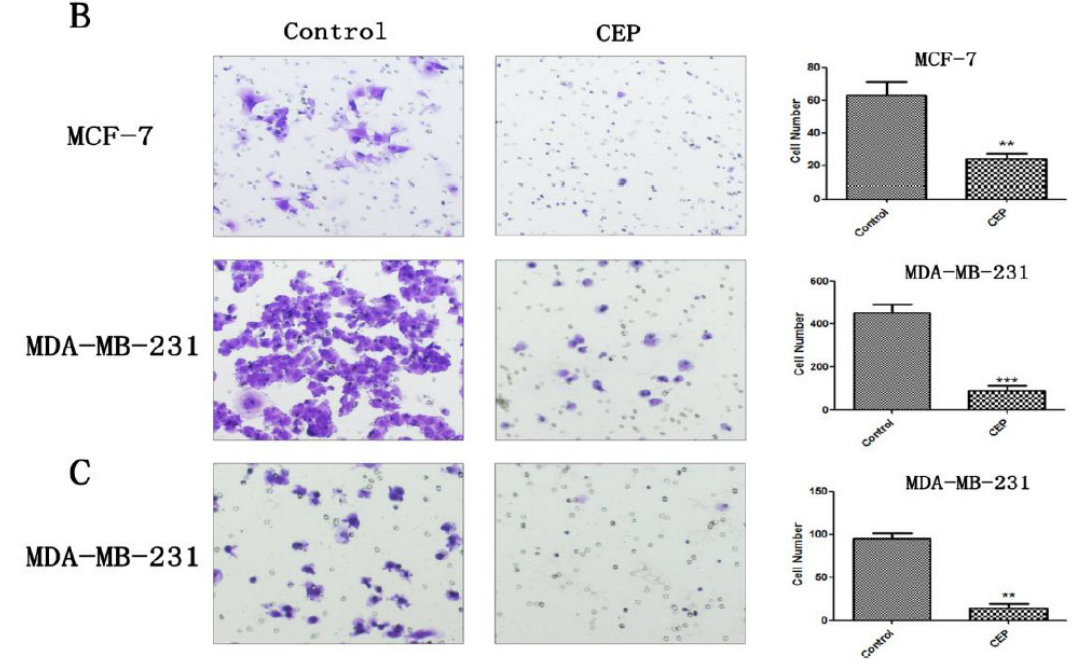

Fig. 2. Cell motility was inhibited by CEP in migration, invasion and scratch assays. The scratch assay showed a delayed process of wound healing. Images and wound distance percentage of MCF-7 and MDAMB-231 (A) for $12 \mathrm{~h}, 24 \mathrm{~h}$ after CEP (5 $\mu \mathrm{M}$ for MCF-7, $4 \mu \mathrm{M}$ for MDA-MB-231) treatment. (B) Migration assay of MCF-7 cells treated with CEP (5 $\mu \mathrm{M})$ after $48 \mathrm{~h}$; MDA-MB-231 cells after $18 \mathrm{~h}$, and the cell migration ability was inhibited by CEP $(4 \mu \mathrm{M})$. Invasion assay of MDA-MB-231 cells after $24 \mathrm{~h}$ with CEP $(4 \mu \mathrm{M})$; the cell number were decreased significantly after CEP treatment (C). ${ }^{*} p<0.05 ;{ }^{* *} p<0.01 ;{ }^{* *} p<0.001$ vs. the control group, all experiments were performed in triplicate, and data are presented as the mean \pm SD of three separate experiments.

in CEP-treated cells (Fig. 3A and B). The results revealed that the percentage of cells in the G0/G1 phase at $24 \mathrm{~h}$ increased from 41.65 to $66.07 \%$ in MCF-7 cells with CEP treatment (Fig. 3A). In MDA-MB-231 cells, the results were similar. Cells treated with CEP had an increased percentage of cells in the G0/G1 phase (from 38.79 to $57.78 \%$ ) at $24 \mathrm{~h}$ (Fig. 3B).

\section{KARGER}




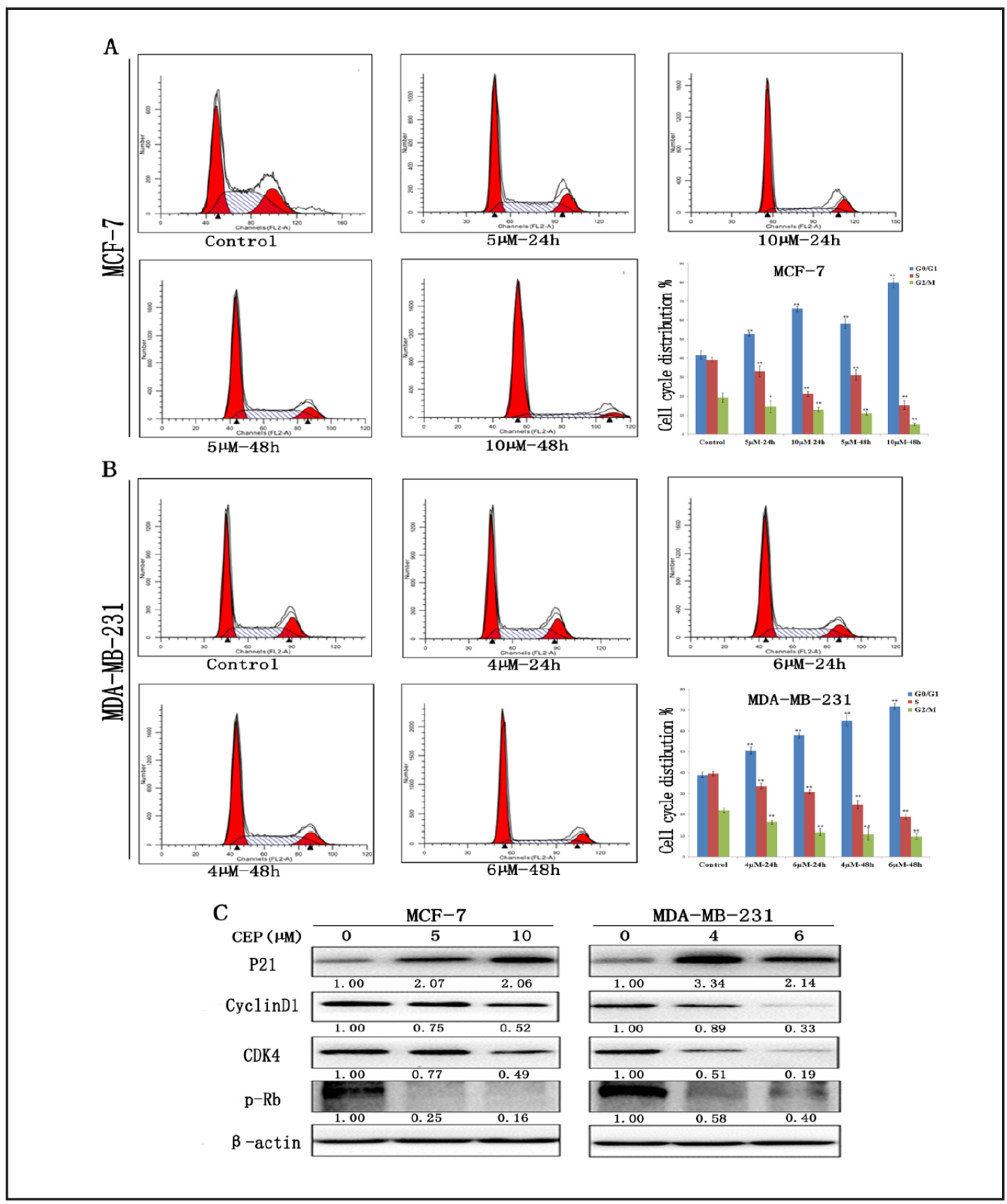

Fig. 3.Induction of G0/G1 phase arrest in MCF-7 (A) and MDA-MB-231 (B) cells by treatment with different concentrations of CEP for $24 \mathrm{~h}$ and $48 \mathrm{~h}$. The DNA content of cells was detected by PI staining and analysed by flow cytometry. (C) MCF-7 and MDA-MB-231 were incubated with CEP at different concentrations for 48 h. The protein levels of P21, Cyclin D1, CDK4, p-Rb (Ser795) were measured by western blotting. * $p<0.05$; ${ }^{* *} p<0.01$; ${ }^{* * *} p<0.001$ vs. the control group, the results are representative of three independent experiments.

The results revealed that CEP-induced G0/G1 arrest of both MCF-7 and MDA-MB-231 cells was significantly higher at $48 \mathrm{~h}$ than at $24 \mathrm{~h}$. The results demonstrated that CEP could induce cell cycle arrest at the G0/G1 phase.

Cell cycle progression is known to be promoted by and inhibited by cyclin-CDK complex inhibitor proteins, including P21. As shown in Fig. 3C, the protein level of P21 was increased, 


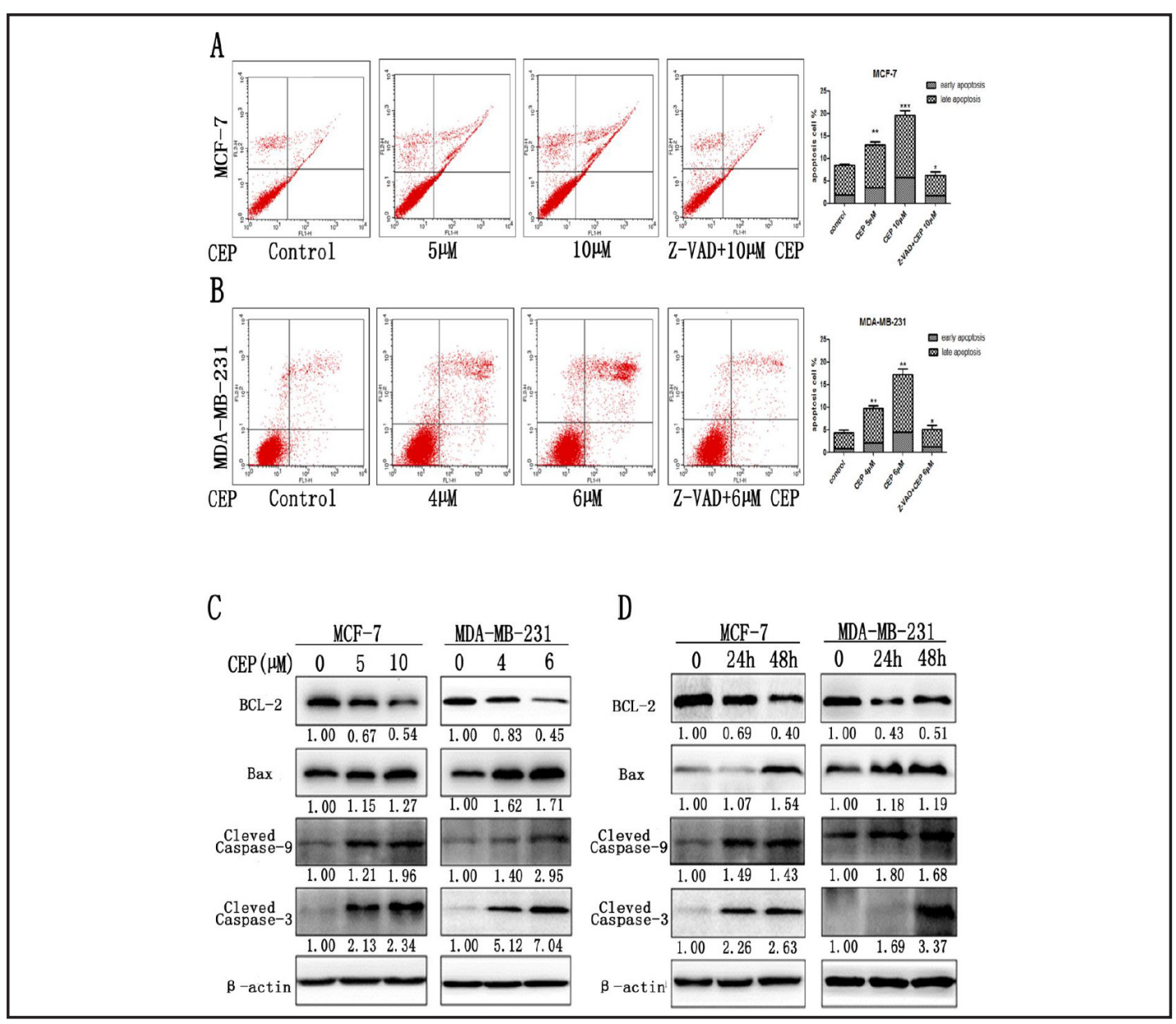

Fig. 4. MCF-7 and MDA-MB-231 cells were incubated with CEP at different concentrations for $48 \mathrm{~h}$. The cells were stained with PI and Annexin V and then detected by flow cytometry. The distributions of early and late apoptosis cells are shown on the lower right (LR) and upper right (UR) quadrants of the histograms, respectively; MCF-7 cells (A) and MDA-MB-231 cells (B). Z-VAD-FMK was added to the culture medium 1 $\mathrm{h}$ before treatment with $10 \mu \mathrm{M}$ CEP (MCF-7 cells) or $6 \mu \mathrm{M}$ CEP (MDA-MB-231 cells). (C) MCF-7 and MDAMB-231 cells were incubated with CEP at different concentrations for $48 \mathrm{~h}$. (D) MCF-7 cells were treated with $10 \mu \mathrm{M}$ CEP, and MDA-MB-231 cells were treated with $6 \mu \mathrm{M}$ CEP for $24 \mathrm{~h}$ or $48 \mathrm{~h}$; then, the effects of CEP on the expression of BCL-2, Bax, Cleaved-caspase- 3 and Cleaved-caspase- 9 protein were analysed by western blotting. * $p<0.05$; ${ }^{* *} p<0.01$; $^{* *} p<0.001$ vs. the control group, the results are representative of three independent experiments.

and the protein levels of Cyclin D1, CDK4, and the downstream p-Rb (Ser795) were decreased in both MCF-7 and MDA-MB-231 cells treated with CEP.

\section{CEP induced cell apoptosis in breast cancer cells}

The effect of CEP on the induction of cell apoptosis in breast cancer cells was measured by PI-Annexin V double staining. As shown in Fig. 4A, treatment with different concentrations of CEP for $48 \mathrm{~h}$ increased the percentage of apoptotic cells from 6.01 to $20.08 \%$ in MCF7 cells. Compared with untreated cells, CEP-treated MDA-MB-231 cells had an increased apoptotic cells ratio (3.82 to $15.26 \%$ ) at $48 \mathrm{~h}$ (Fig. 4B). These data revealed that CEP caused apoptosis in both breast cancer cell lines.

The mechanisms of CEP-induced apoptosis were determined by western blot. As shown in Fig. 4C, D, the expression of BCL-2, Bax, Cleaved-caspase-3 and Cleaved-caspase- 9 were altered significantly in a dose- and time-dependent manner in MCF-7 and MDA-MB-231 cells. 


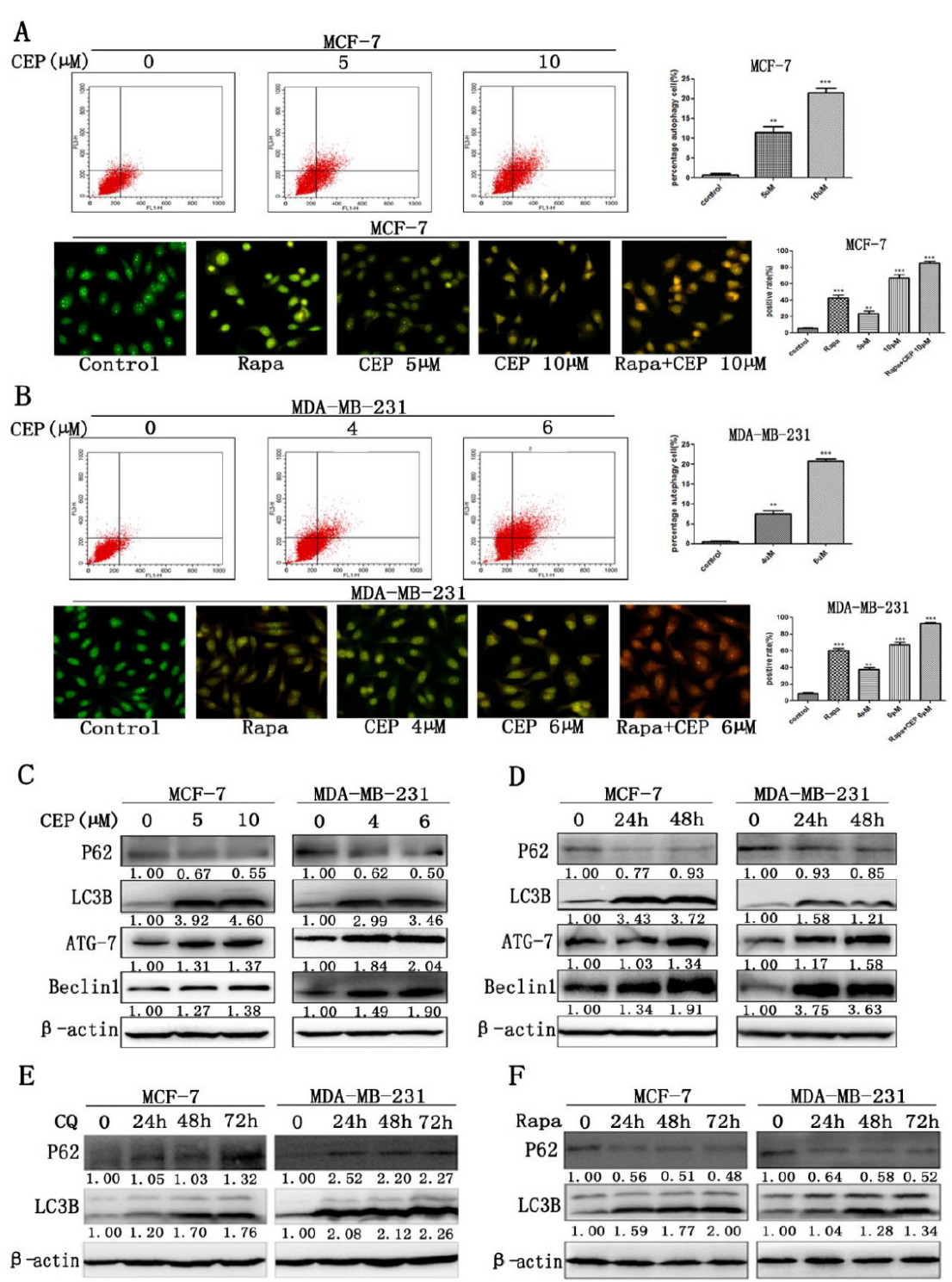

Fig. 5. MCF-7 (A) and MDA-MB-231 (B) cells were labelled with Acridine orange (AO) after CEP treatment for $48 \mathrm{~h}$ and quantified using flow cytometry. FL1-H indicates green colour intensity (cytoplasm and nucleus), and FL3-H shows red colour intensity (AVO). Cells in the upper quadrants were considered AVO-positive. Cells were treated with CEP and/or Rapamycin $(2 \mu \mathrm{g} / \mathrm{mL}$ ) for $48 \mathrm{~h}$; then, MCF-7 (A) and MDA-MB-231 (B) cells were stained with AO and examined under a fluorescence microscope. Rapamycin was used as positive control. (C) MCF-7 and MDA-MB-231 cells were incubated with CEP at different concentrations for $48 \mathrm{~h}$. (D) MCF-7 cells were treated with $10 \mu \mathrm{M}$ CEP, and MDA-MB-231 cells were treated with $6 \mu \mathrm{M}$ CEP for $24 \mathrm{~h}$ or $48 \mathrm{~h}$. Western blot analysis revealed that P62, LC3B, Beclin-1, and ATG-7 protein levels changed significantly with CEP treatment. (E) Effect of autophagy inhibitor chloroquine (CQ), and (F) autophagy inducer rapamycin (Rapa) on LC3B and P62 expression levels in breast cancer. Cells were exposed from $24 \mathrm{~h}$ to $72 \mathrm{~h}$ to 20 $\mu \mathrm{M}$ CQ or to $2 \mu \mathrm{g} / \mathrm{mL}$ Rapa; then, the LC3B and P62 protein levels were detected by western blotting. ** $p<$ $0.01 ;^{* * *} p<0.001$ vs. the control group, the results are representative of three independent experiments.

To confirm that caspases were activated during CEP-induced apoptosis, we treated cells with the pan-caspase inhibitor (Z-VAD-FMK, $40 \mu \mathrm{M}$ ) for $48 \mathrm{~h}$ and investigated the effect of Z-VADFMK on the induction of apoptosis in MCF-7 and MDA-MB-231 cells. The results suggested 
A

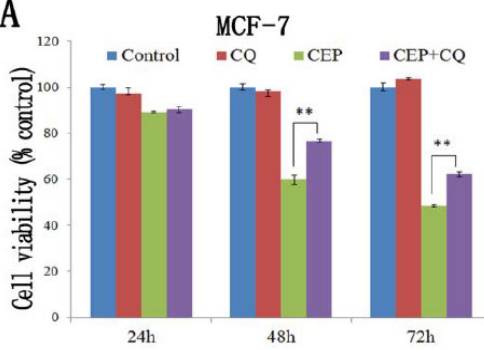

$\mathrm{C}$

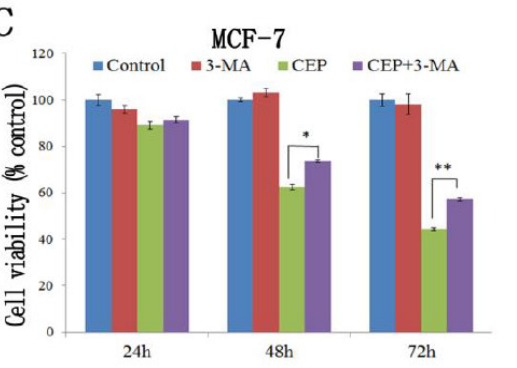

$\mathrm{E}$

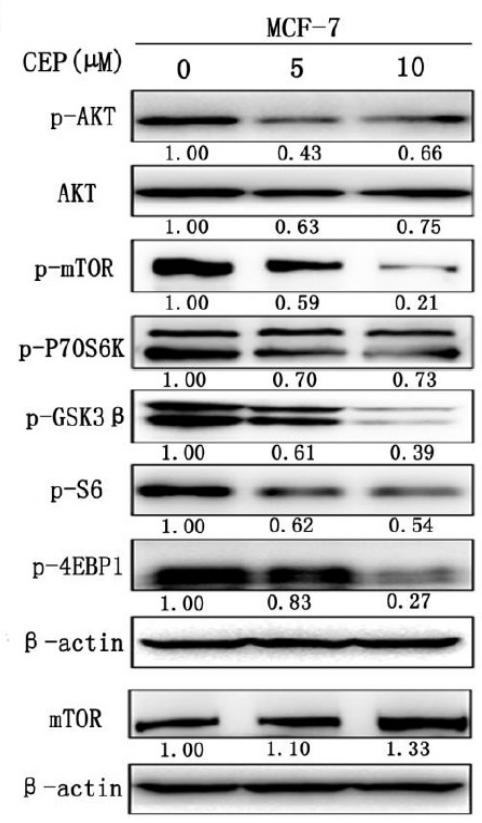

B

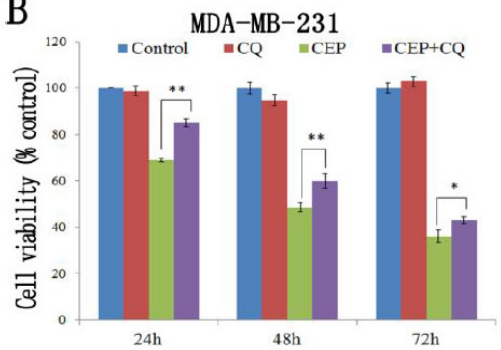

D

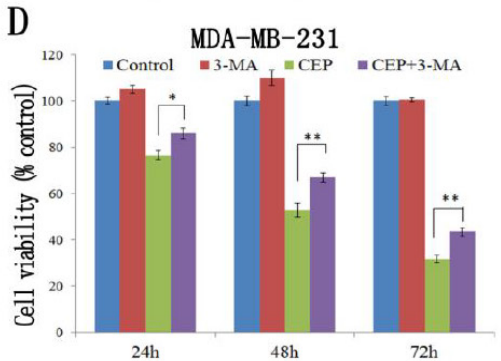

MDA-MB-231

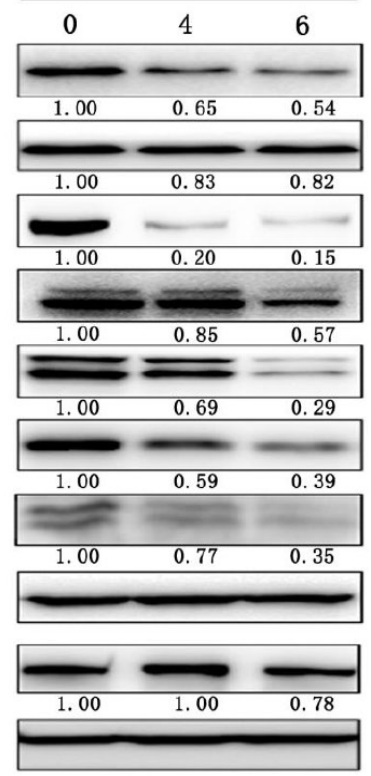

Fig. 6. MCF-7 cells (A and C) and MDA-MB-231 cells (B and D) were pretreated with CQ $(20 \mu \mathrm{M})$ or 3-MA $(4 \mu \mathrm{M})$ for $1 \mathrm{~h}$ before being exposed to CEP $(5 \mu \mathrm{M}$ for MCF-7 cells, $4 \mu \mathrm{M}$ for MDA-MB-231 cells). Cell viability was measured by MTT assay. (E) MCF-7 and MDA-MB-231 cells were incubated with CEP at different concentrations for $48 \mathrm{~h}$; the effect of CEP on the levels of mTOR, p-mTOR, AKT, p-AKT (Ser473), p-P70S6K (Ser371), p-S6 (Ser240/244), p-4E-BP1 (Thr70) and p-GSK3 $\beta$ (Ser21/9) were examined by western blot. * $p<0.05$; ${ }^{* *} p<0.01$. The experiments were performed in triplicate, and data are presented as the mean $\pm \mathrm{SD}$ of three separate experiments.

that caspase activity is required for CEP-induced apoptosis in both breast cancer cell lines (Fig. 4A, B).

CEP induced autophagy in breast cancer cells

To evaluate the effect of CEP on the induction of autophagy cell death in breast cancer cells, flow cytometry analysis and an AVO staining assay were used to quantify cells KARGER 


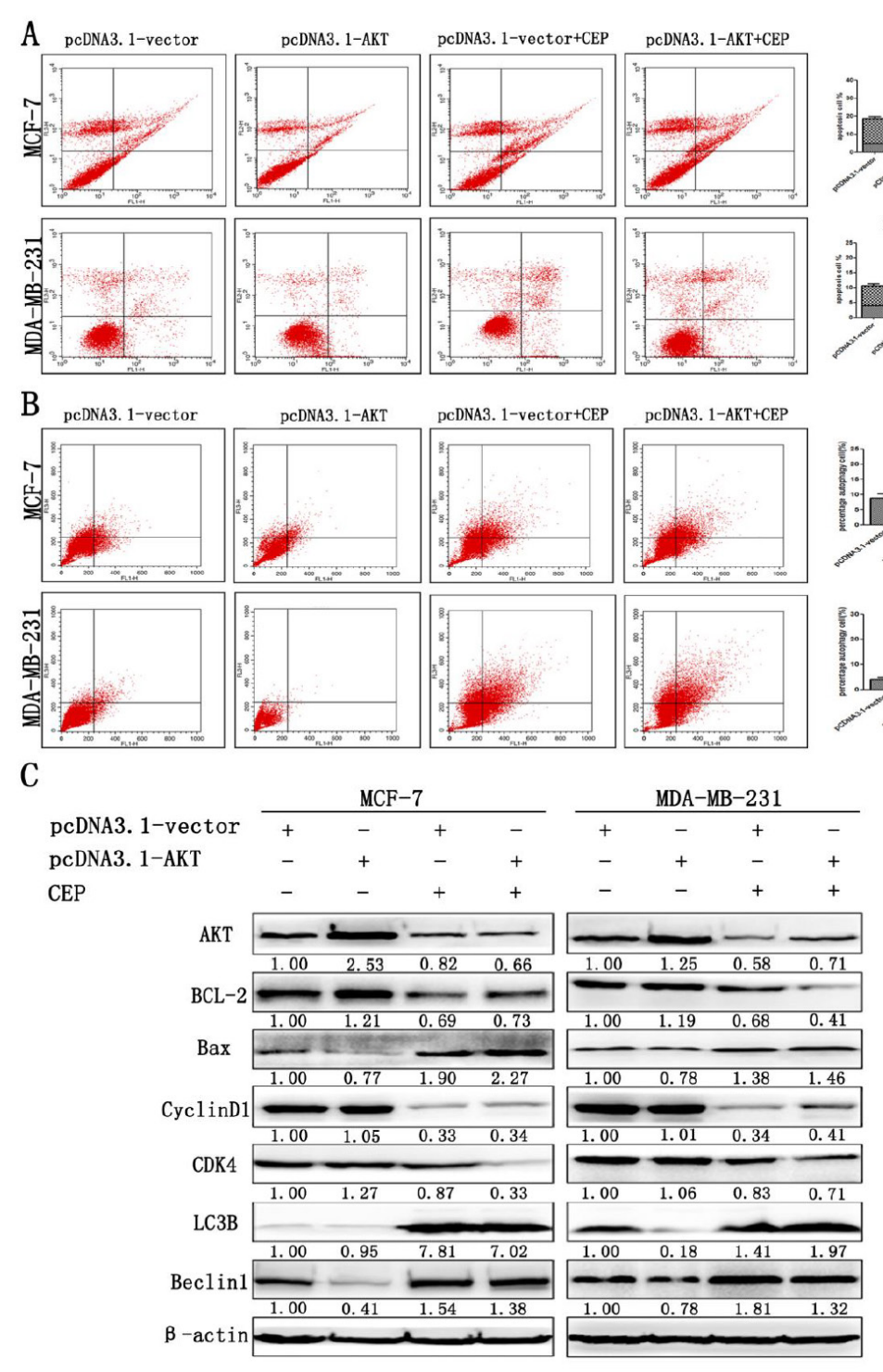

Fig. 7. MCF-7 and MDA-MB-231 cells were transfected with pcDNA3.1-AKT or pcDNA3.1-vector and were then co-treated with $10 \mu \mathrm{M}$ or $6 \mu \mathrm{M}$ CEP or with vehicle control for $48 \mathrm{~h}$. (A) Cells were stained with PI and Annexin V; then, the distributions of early and late apoptotic cells were detected by flow cytometry. (B) MCF-7 and MDA-MB-231 cells were labelled with Acridine orange (AO); FL1-H indicates green colour intensity (cytoplasm and nucleus), and FL3-H shows red colour intensity (AVO). (C) The protein levels of AKT, BCL-2, Bax, LC3B, Beclin-1, Cyclin D1, and CDK4 were examined using western blot. ${ }^{*} p<0.05$; ${ }^{* *} p<0.01$. The experiments were performed in triplicate, and data are presented as the mean \pm SD of three separate experiments.

undergoing autophagy. We observed that CEP enhanced the induction of autophagy in MCF-7 (Fig. 5A) and MDA-MB-231 (Fig. 5B) cells when the cells were treated with various concentrations of CEP for $48 \mathrm{~h}$.

To further investigate the mechanism involved in CEP-mediated cell autophagy, the proteins related to cell autophagy were measured by western blot. As shown in Fig. 5C, D, the levels of LC3B, Beclin1, and ATG-7 were increased, and the level of P62 was decreased significantly in MCF-7 and MDA-MB-231 cells treated with CEP. These data demonstrated 


\section{Cellular Physiology Cell Physiol Biochem 2017;41:1633-1648

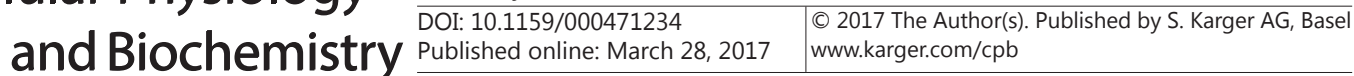

Gao et al.: The Effect of Cepharanthine on Breast Cancer Cells

that CEP induced cell autophagy in a dose- and time-dependent manner in both breast cancer cell lines.

CEP induced autophagy-associated cell death in breast cancer cells

To investigate whether the induction of autophagy contributed to CEP-induced cell death, we treated cells with CQ $(20 \mu \mathrm{M})$ and 3-MA $(4 \mu \mathrm{M})$ for $1 \mathrm{~h}$ before treatment with CEP. Chloroquine (CQ) inhibits lysosome acidification and degradation, and 3-methyladenine (3-MA) is an inhibitor of autophagosome formation [27]. The cytotoxic effect of CEP combined with 3-MA and CQ treatment was measured by MTT assay. As shown in Fig. 6A, C, co-treatment with either CQ or 3-MA significantly decreased the CEP-induced cell death in MCF-7 cells at $48 \mathrm{~h}$ and $72 \mathrm{~h}$. The results observed in MDA-MB-231 cells revealed that co-treatment with either CQ or 3-MA decreased CEP-induced cell death in a time-dependent manner (Fig. 6B, D). LC3B and P62 are the most common autophagic markers. Cells were exposed to the autophagy inhibitor CQ and the autophagy inducer rapamycin (Rapa) from $24 \mathrm{~h}$ to $72 \mathrm{~h}$. The results revealed that CQ could increase LC3B and P62 (Fig. 5E) in breast cancer cells. However, the P62 level was decreased, and LC3B was increased after Rapa treatment (Fig. 5F). These data suggest that CEP induced autophagy cell death in both breast cancer cell lines.

\section{CEP regulated AKT/mTOR signalling pathway in breast cancer cells}

To further elucidate the potential mechanisms of CEP on apoptosis and autophagy, we investigated whether the AKT/mTOR pathway was involved in CEP-induced apoptosis and autophagy in MCF-7 and MDA-MB-231 cells. As shown in Fig. 6E, phosphorylated AKT (Ser473) and phosphorylated mTOR were decreased, and the mTOR downstream targets p70S6K (Ser371), p-S6 (Ser240/244) and p-4E-BP1 (Thr70) were reduced significantly after treatment with CEP. AKT can induce changes in cell cycle distribution [28]. GSK3 $\beta$ is a downstream effector of AKT, and as an upstream regulator of Cyclin D1 [29]. Compared with the control group, the level of p-GSK3 $\beta$ (Ser21/9) was decreased in CEP-treated cells (Fig. $6 \mathrm{E})$.

\section{CEP inhibited AKT in breast cancer cells}

To further confirm whether CEP-induced apoptosis and autophagy is AKT-independent, we demonstrated the effect of AKT expression on breast cancer cells using flow cytometry analysis and western blot. As shown in Fig. 7A, B, pcDNA3.1-AKT transfection together with CEP treatment altered the number of apoptotic and autophagic cells when compared to pcDNA3.1-AKT transfection without CEP treatment in MCF-7 and MDA-MB-231 cells. These results revealed that CEP-induced apoptosis and autophagy might be Akt-specific or Aktdependent in breast cancer cells. In Fig. 7C, AKT overexpression downregulated Bax, Beclin1, and LC3B, upregulated BCL-2 and partially reversed the suppression of Cyclin D1 and CDK4 protein levels. However, compared with AKT overexpression alone, Bax, Beclin1, and LC3B were increased, and BCL-2, CyclinD1 and CDK4 were decreased in both AKT-transfected breast cancer cell lines treated with CEP.

\section{Discussion}

TCM has been confirmed to be effective in the treatment of a number of tumours [30, 31]. CEP is a biscoclaurine alkaloid extracted from Stephania cepharantha [17]. In a previous clinical study, CEP had effects on adjuvant chemotherapy-induced bone marrow suppression, leukopenia and thrombocytopenia in breast cancer patients [32, 33]; however, the anti-tumour effect of CEP on breast cancer is unclear.

In our study, we found that CEP could inhibit cell proliferation and motility. MTT and clone formation assays showed that CEP inhibited cell proliferation in a time- and dosedependent manner in MCF-7 and MDA-MB-231 cells. After treatment with CEP, we observed reductions in cell motility, which were measured by scratch, migration and invasion 
assays. Previous studies have shown that CEP induces apoptosis in myeloma cells [18] and hepatocellular carcinoma [34]. However, whether CEP can induce apoptosis in breast cancer cells is unknown. Our finding demonstrated that CEP induces cell apoptosis in two breast cancer cell lines. The underlying mechanism of CEP-induced apoptosis in breast cancer cells was assessed by western blot. The mitochondrial pathway is an important mediator of cell apoptosis, and the BCL-2 family has an important role in the mitochondrial pathway [35]. BCL-2 family members include anti-apoptotic BCL-2 protein and pro-apoptotic Bax protein [36]. Bax-induced growth arrest is associated with the release of cytochrome $\mathrm{C}$ from mitochondria, which is blocked by BCL-2 [37]. In intrinsic apoptotic stimulation, cytochrome $c$ is released into the cytosol, where it triggers the formation of the apoptosome, which activates caspase- 9 [38]. The caspase-9/apoptosome complex then targets and activates the effector caspase 3 [39]. In our study, CEP induced apoptosis by increasing the Bax/BCL-2 ratio and by activating Cleaved-caspase- 3 and Cleaved-caspase-9, as measured by western blot. Furthermore, our results showed that Z-VAD-FMK blocked CEP-induced apoptosis, as revealed by the PI-Annexin V assay. The results demonstrated that CEP could induce apoptosis by activating the intrinsic mitochondria-mediated caspase pathway.

In recent years, it has been reported that programmed cell death (PCD) is not confined to apoptosis (type-I PCD) and that cells use different pathways for active self-destruction. Another important programmed cell death pathway is autophagic cell death (type-II PCD) [40]. A previous study has demonstrated that autophagy can improve anticancer therapy [41]. During the autophagy process, portions of the cytoplasm are sequestered within doublemembrane vesicles known as autophagy vacuoles, which then fuse with lysosomes to form single-membrane autophagolysosomes [42]. LC3 is important for autophagosome formation and function, and it is conjugated by Atg7. P62 is incorporated in completed autophagosomes and degraded in autolysosomes $[43,44]$. In our study, we investigated CEP-induced autophagy by using an acidic vesicular organelle (AVO) staining assay and flow cytometry analysis. Using western blot analysis, we examined LC3B, Beclin1, ATG-7, and P62 protein levels after treatment with CEP. To further investigate whether CEP-induced autophagy could affect its antitumour activity, we conducted two combination experiments with autophagy inhibitors 3-MA and CQ and then examined cell viability via the MTT assay. Furthermore, we detected the protein levels of LC3B and P62 in MCF-7 and MDA-MB-231 cells after treatment with CQ or Rapa. These results suggested that CEP induced autophagy in both breast cancer cell lines.

It has been reported that CEP can induce G0/G1 cell cycle arrest in myeloma cells [18]. In an earlier study, it was demonstrated that P21 is a cyclin-dependent kinase inhibitor [45]. CyclinD1 is a key regulator in G1 progression, and the cyclin D/Cdk complexes could phosphorylate Rb directly [46, 47]. GSK3 $\beta$ is a downstream effector of AKT and an upstream regulator of Cyclin D1 [29]. In our study, we investigated CEP-induced cell cycle arrest by flow cytometry analysis. Furthermore, the underlying mechanism of G0/G1 arrest was determined by western blot. Our results indicated that CEP could induce cell cycle arrest in the G0/G1 phase, and CEP-induced G0/G1 arrest might occur through inhibition of the AKT/ GSK3 $\beta /$ Cyclin D1/p-Rb pathway.

A previous study has shown that CEP can induce apoptosis in hepatocellular cancer cells and in leukaemia cells via downregulation of Akt [34]. AKT signalling has an important role in the regulation of cell proliferation, angiogenesis, migration and invasion [48]. Numerous studies revealed that mTOR kinase could suppress autophagy and apoptosis [49]. Our results demonstrated that phosphorylated AKT and phosphorylated mTOR were decreased in both breast cancer cell lines after CEP treatment. These data demonstrated that CEP might induce apoptosis and autophagy in breast cancer cells by inhibiting the AKT/ mTOR signalling pathway. In our study, overexpression of AKT could induce apoptosis and autophagy following CEP treatment, as measured by flow cytometry analysis and western blot. Furthermore, the expression level of Bax was upregulated and the suppression of AKT/BCL-2/CyclinD1/CDK4 was partially reversed after overexpression of AKT alone and in combination with CEP treatment. These results indicated that there are likely other functional mediators of CEP-induced apoptosis and autophagy in breast cancer cells. 


\section{Cellular Physiology Cell Physiol Biochem 2017;41:1633-1648 \begin{tabular}{ll|l} 
and Biochemistry & $\begin{array}{l}\text { DOI: 10.1159/000471234 } \\
\text { Published onlIne: VIarch 28, } 2017\end{array}$ & $\begin{array}{l}\text { @ 2017 The Author(s). Published by S. Karger AG, Basel } \\
\text { www.karger.com/cpb }\end{array}$ \\
\hline
\end{tabular}}

In conclusion, for the first time, our results demonstrate that CEP can inhibit cell proliferation by inducing apoptosis, autophagy and G0/G1 arrest in ER-positive and ERnegative breast cancer cells. Moreover, we demonstrated that the AKT/mTOR signalling pathway contributes to CEP-induced cell death in breast cancer cells. The deeper molecular mechanisms of CEP-induced apoptosis and autophagy should be examined in future studies. This study provides evidence that CEP could be a potential drug for clinical therapy of breast cancer.

\section{Acknowledgments and Fundings}

This work was supported by the National Natural Science Foundation of China (No. 81272903; No. 81672613), Key Research and Development Program of Shandong Province (No. 2016GGE2775, 2015GSF118093), and Special Support Plan for National High Level Talents ("Ten Thousand Talents Program") to Qifeng Yang.

\section{Disclosure Statement}

No, there is no conflict of interest that I should disclose, having read the above statement.

\section{Reference}

1 Yedjou C, Izevbigie E, Tchounwou P: Preclinical assessment of vernonia amygdalina leaf extracts as DNA damaging anti-cancer agent in the management of breast cancer. Int J Environ Res Public Health 2008;5:337-341.

-2 Chen W, Zheng R, Baade PD, Zhang S, Zeng H, Bray F, Jemal A, Yu XQ He J: Cancer statistics in China, 2015. CA Cancer J Clin 2016;66:115-132.

-3 DeSantis CE, Lin CC, Mariotto AB, Siegel RL, Stein KD, Kramer JL, Alteri R, Robbins AS, Jemal A: Cancer treatment and survivorship statistics, 2014. CA Cancer J Clin 2014;64:252-271.

4 da Rocha AB, Lopes RM, Schwartsmann G: Natural products in anticancer therapy. Curr Opin Pharmacol 2001;1:364-369.

5 Lee KH: Anticancer drug design based on plant-derived natural products. J Biomed Sci 1999;6:236-250.

6 Pu CY, Lan VM, Lan CF, Lang HC: The determinants of traditional Chinese medicine and acupuncture utilization for cancer patients with simultaneous conventional treatment. Eur J Cancer Care (Engl) 2008;17:340-349.

7 Chen J, Lin C, Yong W, Ye Y, Huang Z: Calycosin and genistein induce apoptosis by inactivation of HOTAIR/pAkt signaling pathway in human breast cancer MCF-7 cells. Cell Physiol Biochem 2015;35:722-728.

8 Chen J, Ge B, Wang Y, Ye Y, Zeng S, Huang Z: Biochanin A promotes proliferation that involves a feedback loop of microRNA-375 and estrogen receptor alpha in breast cancer cells. Cell Physiol Biochem 2015;35:639-646.

9 Nie J, Zhao C, Deng LI, Chen J, Yu B, Wu X, Pang P, Chen X: Efficacy of traditional Chinese medicine in treating cancer. Biomed Rep 2016;4:3-14.

10 Zhu L, Li L, Li Y, Wang J, Wang Q: Chinese Herbal Medicine as an Adjunctive Therapy for Breast Cancer: A Systematic Review and Meta-Analysis. Evid Based Complement Alternat Med 2016;2016:9469276.

11 Song X, Li Y, Zhang H, Yang Q: The anticancer effect of Huaier (Review). Oncol Rep 2015;34:12-21.

12 Li Y, Qi W, Song X, Lv S, Zhang H, Yang Q: Huaier extract suppresses breast cancer via regulating tumorassociated macrophages. Sci Rep 2016;6:20049.

13 Wang X, Qi W, Li Y, Zhang N, Dong L, Sun M, Cun J, Zhang Y, Lv S, Yang Q: Huaier Extract Induces Autophagic Cell Death by Inhibiting the mTOR/S6K Pathway in Breast Cancer Cells. PLoS One 2015;10:e0131771.

-14 Zhang N, Kong X, Yan S, Yuan C, Yang Q: Huaier aqueous extract inhibits proliferation of breast cancer cells by inducing apoptosis. Cancer Sci 2010;101:2375-2383. 


\section{Cellular Physiology Cell Physiol Biochem 2017;41:1633-1648

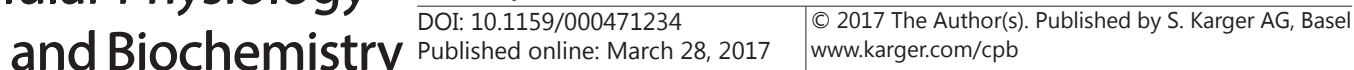

15 Qi W, Sun M, Kong X, Li Y, Wang X, Lv S, Ding X, Gao S, Cun J, Cai C, Wang X, Chen J, Yin A, Yang Q: Huaier extract synergizes with tamoxifen to induce autophagy and apoptosis in ER-positive breast cancer cells. Oncotarget 2016;7:26003-26015.

16 Ding X, Yang Q, Kong X, Haffty BG, Gao S, Moran MS: Radiosensitization effect of Huaier on breast cancer cells. Oncol Rep 2016;35:2843-2850.

17 Tomita M, Fujitani K, Aoyagi Y: Synthesis of dl-cepharanthine. Tetrahedron Lett 1967;13:1201-1206.

-18 Kikukawa Y, Okuno Y, Tatetsu H, Nakamura M, Harada N, Ueno S, Kamizaki Y, Mitsuya H, Hata H: Induction of cell cycle arrest and apoptosis in myeloma cells by cepharanthine, a biscoclaurine alkaloid. Int J Oncol 2008;33:807-814.

19 Harada K, Ferdous T, Itashiki Y, Takii M, Mano T, Mori Y, Ueyama Y: Cepharanthine inhibits angiogenesis and tumorigenicity of human oral squamous cell carcinoma cells by suppressing expression of vascular endothelial growth factor and interleukin-8. Int J Oncol 2009;35:1025-1035.

20 Law BY, Chan WK, Xu SW, Wang JR, Bai LP, Liu L, Wong VK: Natural small-molecule enhancers of autophagy induce autophagic cell death in apoptosis-defective cells. Sci Rep 2014;4:5510.

21 Okada K, Sakusabe N, Kobayashi A, Hoshi N, Sato K: Prevention of lung metastasis by intra-tumoral injection of Cepharanthin and staphylococcal enterotoxin B in transplantable rat osteosarcoma. Jpn J Cancer Res 1999;90:928-933.

22 Ikeda R, Che XF, Yamaguchi T, Ushiyama M, Zheng CL, Okumura H, Takeda Y, Shibayama Y, Nakamura K, Jeung HC, Furukawa T, Sumizawa T, Haraguchi M, Akiyama S, Yamada K: Cepharanthine potently enhances the sensitivity of anticancer agents in K562 cells. Cancer Sci 2005;96:372-376.

23 Nakajima A, Yamamoto Y, Taura K, Hata K, Fukumoto M, Uchinami H, Yonezawa K, Yamaoka Y: Beneficial effect of cepharanthine on overcoming drug-resistance of hepatocellular carcinoma. Int J Oncol 2004;24:635-645.

-24 Kono K, Takahashi JA, Ueba T, Mori H, Hashimoto N, Fukumoto M: Effects of combination chemotherapy with biscoclaurine-derived alkaloid (Cepharanthine) and nimustine hydrochloride on malignant glioma cell lines. J Neurooncol 2002;56:101-108.

25 Tamatani T, Azuma M, Motegi K, Takamaru N, Kawashima Y, Bando T: Cepharanthin-enhanced radiosensitivity through the inhibition of radiation-induced nuclear factor-kappaB activity in human oral squamous cell carcinoma cells. Int J Oncol 2007;31:761-768.

26 Furusawa S, Wu J: The effects of biscoclaurine alkaloid cepharanthine on mammalian cells: implications for cancer, shock, and inflammatory diseases. Life Sci 2007;80:1073-1079.

27 Mizushima N, Yoshimori T, Levine B: Methods in mammalian autophagy research. Cell 2010;140:313-326.

28 Yen CC, Hsiao CD, Chen WM, Wen YS, Lin YC, Chang TW, Yao FY, Hung SC, Wang JY, Chiu JH, Wang HW, Lin $\mathrm{CH}$, Chen TH, Chen PC, Liu CL, Tzeng CH, Fletcher JA: Cytotoxic effects of 15d-PGJ2 against osteosarcoma through ROS-mediated AKT and cell cycle inhibition. Oncotarget 2014;5:716-725.

-29 Takahashi-Yanaga F, Sasaguri T: GSK-3beta regulates cyclin D1 expression: a new target for chemotherapy. Cell Signal 2008;20:581-589.

-30 Xu H, Zhao X, Liu X, Xu P, Zhang K, Lin X: Antitumor effects of traditional Chinese medicine targeting the cellular apoptotic pathway. Drug Des Devel Ther 2015;9:2735-2744.

-31 Yun M, Lee D, Park MN, Kim EO, Sohn EJ, Kwon BM, Kim SH: Cinnamaldehyde derivative (CB-PIC) sensitizes chemo-resistant cancer cells to drug-induced apoptosis via suppression of MDR1 and its upstream STAT3 and AKT signalling. Cell Physiol Biochem 2015;35:1821-1830.

-32 Suzuki S, Abe R, Nihei M, Kimijima I, Tsuchiya A, Nomizu T: [Efficacy of Cepharanthin for preventing leukopenia and thrombocytopenia induced by chemotherapy in breast cancer patient--prospective randomized study]. Gan To Kagaku Ryoho 1990;17:1195-1200.

33 Tsukikawa S, Oikawa H, Satoh T, Morikubo M, Komoriyama H, Hagiwara M, Kanasugi K, Yamaguchi S: [The effect of cepharanthin on adjuvant chemotherapy induced bone marrow suppression in patients with breast cancer]. Gan To Kagaku Ryoho 1990;17:645-648.

34 Biswas KK, Tancharoen S, Sarker KP, Kawahara K, Hashiguchi T, Maruyama I: Cepharanthine triggers apoptosis in a human hepatocellular carcinoma cell line (HuH-7) through the activation of JNK1/2 and the downregulation of Akt. FEBS Lett 2006;580:703-710.

-35 Adams JM, Cory S: The Bcl-2 protein family: arbiters of cell survival. Science 1998;281:1322-1326.

-36 Kim R: Unknotting the roles of Bcl-2 and Bcl-xL in cell death. Biochem Biophys Res Commun 2005;333:336-343. 


\section{Cellular Physiology Cell Physiol Biochem 2017;41:1633-1648 \begin{tabular}{l|l} 
DOI: 10.1159/000471234 & $\begin{array}{l}\text { O 2017 The Author(s). Published by S. Karger AG, Basel } \\
\text { www.karger.com/cpb }\end{array}$ \\
\hline
\end{tabular}

-37 Manon S, Chaudhuri B, Guerin M: Release of cytochrome c and decrease of cytochrome c oxidase in Baxexpressing yeast cells, and prevention of these effects by coexpression of Bcl-xL. FEBS Lett 1997;415:2932.

-38 Adrain C, Slee EA, Harte MT, Martin SJ: Regulation of apoptotic protease activating factor-1 oligomerization and apoptosis by the WD-40 repeat region. J Biol Chem 1999;274:20855-20860.

39 Henry-Mowatt J, Dive C, Martinou JC, James D: Role of mitochondrial membrane permeabilization in apoptosis and cancer. Oncogene 2004;23:2850-2860.

-40 Bursch W, Ellinger A, Gerner C, Frohwein U, Schulte-Hermann R: Programmed cell death (PCD). Apoptosis, autophagic PCD, or others? Ann N Y Acad Sci 2000;926:1-12.

41 Moretti L, Yang ES, Kim KW, Lu B: Autophagy signaling in cancer and its potential as novel target to improve anticancer therapy. Drug Resist Updat 2007;10:135-143.

42 Klionsky DJ, Emr SD: Autophagy as a regulated pathway of cellular degradation. Science 2000;290:17171721.

43 Barth S, Glick D, Macleod KF: Autophagy: assays and artifacts. J Pathol 2010;221:117-124.

44 Klionsky DJ, Abdelmohsen K, Abe A, Abedin MJ, Abeliovich H, Acevedo Arozena A, Adachi H, Adams CM, Adams PD, Adeli K, Adhihetty PJ, Adler SG, Agam G, Agarwal R, Aghi MK, Agnello M, Agostinis P, Aguilar PV, Aguirre-Ghiso J, et al.: Guidelines for the use and interpretation of assays for monitoring autophagy (3rd edition). Autophagy 2016;12:1-222.

45 Gartel AL, Tyner AL: The role of the cyclin-dependent kinase inhibitor p21 in apoptosis. Mol Cancer Ther 2002;1:639-649.

46 Quelle DE, Ashmun RA, Shurtleff SA, Kato JY, Bar-Sagi D, Roussel MF, Sherr CJ: Overexpression of mouse D-type cyclins accelerates G1 phase in rodent fibroblasts. Genes Dev 1993;7:1559-1571.

47 Matsushime H, Quelle DE, Shurtleff SA, Shibuya M, Sherr CJ, Kato JY: D-type cyclin-dependent kinase activity in mammalian cells. Mol Cell Biol 1994;14:2066-2076.

48 Manning BD, Cantley LC: AKT/PKB signaling: navigating downstream. Cell 2007;129:1261-1274.

49 Wang F, Mao Y, You Q, Hua D, Cai D: Piperlongumine induces apoptosis and autophagy in human lung cancer cells through inhibition of PI3K/Akt/mTOR pathway. Int J Immunopathol Pharmacol 2015;28:362373. 